\title{
Neonatal pain: knowledge, attitude and practice of the nursing team
}

\author{
Dor neonatal: conhecimento, atitude e prática da equipe de enfermagem
}

\author{
Ana Paula Silva Campos ${ }^{1}$
}

DOI 10.5935/2595-0118.20180067

\section{ABSTRACT}

BACKGROUND AND OBJECTIVES: Neonates have special peculiarities, and these should be much more widespread in the scientific environment, both for the knowledge of professionals and students, and for the mothers' help. The objective of this study was to evaluate the knowledge, attitude and practice of the nursing team in management of neonatal pain.

CONTENTS: This is a bibliographical research with a descriptive study conducted from 2013 to 2017, through a survey in the Medline (International Literature in Health Sciences), Scielo (Scientific Electronic Library Online) and LILACS (Latin American Literature in Health Sciences) electronic database. Twenty scientific articles were selected and detailed studied with the purpose of grouping the similar information and verify its particularities to be exposed in categories.

CONCLUSION: There is a need to insert this theme in undergraduate and postgraduate courses and training in maternity units on a continuous basis so that the professional can relate the theory to practice and then offer the best therapy to the newborn and orientations to the mothers.

Keywords: Attitude, Knowledge, Neonatology, Nursing, Pain, Practice.

\section{RESUMO}

JUSTIFICATIVA E OBJETIVOS: Os neonatos possuem particularidades especiais e estas devem ser bem mais difundidas no meio científico, tanto para conhecimento dos profissionais e estudantes, quanto para auxílio das mães. $\mathrm{O}$ objetivo deste estudo foi avaliar o conhecimento, atitude e prática da equipe de enfermagem diante do manuseio da dor neonatal.

CONTEÚDO: Trata-se de uma pesquisa bibliográfica com estudo descritivo, no período de 2013 a 2017, através de um levantamento em base de dados eletrônicos da Medline (Literatura Internacional em Ciências da Saúde), Scielo (Scientific Electron-

1. Universidade Paulista, Faculdade de Enfermagem, Brasilia, DF, Brasil.

Submitted on May 25, 2018.

Accepted for publication on September 17, 2018.

Conflict of interests: none - Sponsoring sources: none.

Correspondence to:

SGAS Quadra 913, s/no - Conjunto B - Asa Sul

70390-130 Brasilia, DF, Brasil.

E-mail: anapaulacampos2@hotmail.com

(C) Sociedade Brasileira para o Estudo da Dor ic Library Online) e LILACS (Literatura Latino Americana em Ciências da Saúde). Foram selecionados 20 artigos científicos, os quais passaram por um estudo minucioso a fim de agrupar os dados semelhantes e verificar suas particularidades, para assim serem expostos em categorias.

CONCLUSÃO: Há a necessidade de inserção dessa temática nos cursos de graduação, pós-graduação e treinamentos e capacitaçôes nas maternidades de forma contínua, a fim de que o profissional consiga relacionar a teoria à prática e oferecer então a melhor terapêutica ao recém-nascido e orientaçôes às mães.

Descritores: Atitude, Conhecimento Dor, Enfermagem, Neonatologia, Prática.

\section{INTRODUCTION}

The International Association for the Study of Pain refers to pain as an unpleasant sensory and emotional experience, added to a tissue injury that is real, potential, or spoken regarding such injury. In this context, it is understood that the pain of each person is individual, and it is revealed through body responses and behavior, involving genetic, mental, affective, and cultural variables ${ }^{1}$. Before the 1980s, it was believed that the newborns (NB) did not feel pain since the insufficiency of the myelination (substance responsible for the conduction of the nerve impulses) in the brain and the lack of memory for pain showed the immaturity of the central nervous system.

However, recent researches point out that the pain receptors undergo complete myelination between the $2^{\text {nd }}$ and $3^{\text {rd }}$ week of pregnancy and the pain pathways originated in the brain are fully myelinated as of the $30^{\text {th }}$ week $^{2}$.

Health experts know that the NB is exposed to several phenomena, both due to institutional standards and routines, and the intricate work process, which involves environments with high luminosity, artificial temperature, noise, and many handlings, putting their bodies through stress since birth ${ }^{3}$.

The analysis of pain featured as the fifth vital sign is not simple to perform since the evaluation is always subjective and, therefore, the professionals need the patients' report. So far, there is not a widely accepted method, of easy and standard administration to assess the pain in the NB. Regardless of the lack of speech, the pain in the NB can be analyzed with scales, taking body alterations into consideration, such as heart and respiratory rate, blood pressure, oxygen saturation, vagal contraction, palmar sweat, and hormonal changes. Besides, the NB pain can also be studied through behavioral criteria, such as facial expression, sleep state, crying and wakefulness, and body movements associated with physiological parameters ${ }^{4-7}$. 
Nowadays, in addition to pharmacological therapy, the professionals providing neonatal care have alternative measures to alleviate the pain and suffering. Among these measures, the involvement of the parents in the care, grouping the babies and reduce the NB handling, lower the noises and light, and identify the being in an individualized manner ${ }^{8}$.

In this context, the entire neonatology staff, especially the nursing professionals who directly care for the babies need to learn how to identify, evaluate, and treat the pain ${ }^{9}$ not only to avoid or decrease the harmful effects of pain in the NB development and to contribute to a quick recovery, but also to improve the care given.

The pain therapy is part of the care provided by the nursing professionals to the NB. However, despite all the advances and methods used for the assessment and relief, little theoretical and practical knowledge is observed on this issue.

This research is based on the justification that the NB has unique particularities, and the scientific community should be more aware of it to help the professionals, the students, and the mothers.

Therefore, the purpose of this study was to assess the knowledge, attitude, and practice of the nursing team managing the neonatal pain.

\section{CONTENTS}

This is a bibliographical research with a descriptive study, which is justified due to the necessity of analyzing the data without the interference from the researcher.
The guiding question was defined from the topic selection: "What are the advances regarding the nursing knowledge, attitudes, and practices in the clinical management of the neonatal pain"?

To obtain the articles, searches were performed in the online database Medline (International Medical Literature Analysis), Scielo (Scientific Electronic Library Online), and LILACS (Latin American and Caribbean Health Sciences Literature), using the following keywords: pain, analgesia, pain perception, pain management, knowledge, attitude, and practice in health, and healthcare quality.

These searches resulted in 1606 articles. In a first moment, all the articles before 2013 were excluded, remaining 39 publications. Then, the exploratory and systematic reading of these articles was carried out.

As a source of data, 20 articles published from 2013 to 2017 were included, in the Portuguese language, which was available in full and presented relevant data to solve the problem of the research.

The articles published before 2013 that were not in Portuguese and unavailable in full were excluded. Also, dissertations and monographs were eliminated.

The data was tabulated to have clear information about the articles (Table 1). Six categories were created to analyze the professionals' knowledge on how to recognize the neonatal pain, the use of scales to evaluate pain, non-pharmacological ways adopted for the clinical management of the pain, registration of such measurements on the records, knowledge of the team regarding the neonatal pain consequences, and the participation of the nursing professionals in training addressing the clinical management of the neonatal pain.

Table 1. Distribution of the articles

\begin{tabular}{|c|c|c|c|}
\hline & Authors & Purpose & Conclusion \\
\hline Article 1 & Mendes et al. ${ }^{10}$ & $\begin{array}{l}\text { Identify the nursing techniques used with the ne- } \\
\text { wborn (NB) with pain in a neonatal intensive care } \\
\text { unit (NICU). }\end{array}$ & $\begin{array}{l}\text { The professionals understand that the NB respond to pain } \\
\text { and that preventive and relieving interventions for pain are } \\
\text { necessary by the staff. }\end{array}$ \\
\hline Article 2 & Alves et al. ${ }^{11}$ & $\begin{array}{l}\text { Discuss the perception of the nursing team regar- } \\
\text { ding the NB pain, identify the attitudes of these } \\
\text { professionals facing the newborn with pain in the } \\
\text { NICU. }\end{array}$ & $\begin{array}{l}\text { It is necessary to provide continuous education programs } \\
\text { to raise professionals' awareness. }\end{array}$ \\
\hline Article 3 & $\begin{array}{l}\text { Wieckzorkievicz } \\
\text { et al. }{ }^{12}\end{array}$ & $\begin{array}{l}\text { Identify the nurse's perception regarding the pain } \\
\text { scale in patients hospitalized in the NICU. }\end{array}$ & $\begin{array}{l}\text { The scales are considered a quick evaluation mechanism } \\
\text { that allows the perception of the pain, and that the diag- } \\
\text { nosis carried out with its use is reliable and feasible for } \\
\text { the service. }\end{array}$ \\
\hline Article 4 & Caetano et al. ${ }^{13}$ & $\begin{array}{l}\text { Describe the ways to evaluate the NB pain used by } \\
\text { the nursing staff and analyze its practice regarding } \\
\text { the management of pain. }\end{array}$ & $\begin{array}{l}\text { There is a need to train the professionals, contributing to } \\
\text { the evaluation and management of pain, and promoting } \\
\text { the integral care to the NB. }\end{array}$ \\
\hline Article 5 & Rosário et al. ${ }^{14}$ & $\begin{array}{l}\text { Analyze the nursing care to the NB in pain in the } \\
\text { NICU. }\end{array}$ & $\begin{array}{l}\text { There is a need to perform a greater reflection on the theo- } \\
\text { retical and practical knowledge regarding the care with the } \\
\text { NB in painful situations, as well as using the scales for } \\
\text { the evaluation and the physiological effects of pain since } \\
\text { certain inconsistency was observed between knowledge } \\
\text { and practice. }\end{array}$ \\
\hline Article 6 & Capellini et al. ${ }^{15}$ & $\begin{array}{l}\text { Analyze the knowledge and attitude of the doctors, } \\
\text { nurses, and nursing assistants who work at a NICU } \\
\text { of a São Paulo's hospital regarding the evaluation } \\
\text { and management of the acute neonatal pain. }\end{array}$ & $\begin{array}{l}\text { The health professionals have expertise in neonatal pain; } \\
\text { however, such knowledge does not reflect on the neona- } \\
\text { tal practice. The professional training based on the trans- } \\
\text { fer of knowledge for the implementation of neonatal pain } \\
\text { evaluation and management is essential. }\end{array}$ \\
\hline
\end{tabular}


Table 1. Distribution of the articles - continuation

\begin{tabular}{|c|c|c|}
\hline & Authors & Purpose \\
\hline Article 7 & Amaral et al. ${ }^{16}$ & $\begin{array}{l}\text { Characterize the nursing staff and identify the ways } \\
\text { to evaluate and manage pain in the premature NB. }\end{array}$ \\
\hline Article 8 & $\begin{array}{l}\text { Cordeiro and } \\
\text { Costa }^{17}\end{array}$ & $\begin{array}{l}\text { Elaborate, with the nursing staff, a proposal of a } \\
\text { service protocol based on non-pharmacological } \\
\text { methods to manage the discomfort and the pain in } \\
\text { the NB hospitalized in the NICU. }\end{array}$ \\
\hline Article 9 & Ribeiro et al. ${ }^{18}$ & $\begin{array}{l}\text { Identify, based on scientific evidence, the benefit } \\
\text { of using aquatic therapy to reduce pain in a patient } \\
\text { hospitalized in a private NICU. }\end{array}$ \\
\hline Article 10 & Leite et al. ${ }^{19}$ & $\begin{array}{l}\text { Compare the combination of the skin-to-skin con- } \\
\text { tact with breastfeeding during the vaccination } \\
\text { against hepatitis B in NB. }\end{array}$ \\
\hline Article 11 & Blasi et al. ${ }^{20}$ & $\begin{array}{l}\text { Analyze the perception of the nursing staff regar- } \\
\text { ding the pain evaluation and management perfor- } \\
\text { med in a pediatric hospitalization sector. }\end{array}$ \\
\hline Article 12 & Araujo et al. ${ }^{21}$ & $\begin{array}{l}\text { Describe the nursing staff strategies in the identifi- } \\
\text { cation, evaluation, and interventions of pain in NB } \\
\text { hospitalized in the NICU. }\end{array}$ \\
\hline
\end{tabular}

Article 13 Monfrim et al. ${ }^{22}$ Learn about the perception of nurses regarding the use of an instrument to evaluate the pain in premature NB.

Article 14 Costa et al. ${ }^{23}$

Article 15 Soares et al. ${ }^{24}$

Check the knowledge and practices of the nurses regarding the management of pain in NB hospitalized at the NICU.

Soares et al. ${ }^{24} \quad$ Evaluate the knowledge, attitude, and practice of the nursing team in the management of the NB pain according to the professional training.

Article 16 Rodrigues, Sou- Analyze the knowledge of the nursing professioza and Wer- nals in the process of identifying, evaluating, and neck $^{25}$ acting in the control of the pain in NB hospitalized at three NICU.

Article 17 da Costa et al. ${ }^{26}$ Analyze the perception of the nurses on the pain clinic in the NB at the NICU.

Article 18 Martins, Enumo Describe and analyze how the NICU organizational and Paula ${ }^{27}$

Article 19 Christoffe al. $^{28}$

et climate and the responses to stress and coping from the health professionals, as well as their beliefs about prematurity and pain, facilitate or impair their engagement in the management of pain in the hospitalized NB.

et Describe and analyze the attitudes of the health professionals regarding the evaluation and treatment of pain in the NB submitted to painful procedures in the NICU.

Article 20 Sposito et al. ${ }^{29}$ Determine the frequency of pain and check the measures performed for its relief during the seven first days of hospitalization in the NICU, as well identify the type and frequency of the invasive procedures to which the NB were submitted.
Conclusion

The team believes in the capacity of the NB to feel pain, articulated with the physiological and behavioral indicators. However, there is a need for training on the topic.

This initiative contributed for better care given at the neonatal unit, reducing the pain and discomfort experienced by the NB during the hospitalization, resulting in a lower number of sequelae and better quality of life for the NB and the family.

Aquatic therapy is a resource that can be employed in the treatment of NB pain since it provides stability of the vital signs, well-being, and relaxation.

Breastfeeding combined with the maternal skin-to-skin contact may optimize the analgesic effect, contributing to the better recovery of the NB after the procedure.

Lacks knowledge and awareness of the nursing staff about the child's pain.

The pain approach by the nursing professionals was still not being performed systematically at the studied NICU, let alone was based on scientific evidence.

Nurses are not aware of the new technologies used to measure pain. However, everybody indicated being committed to humanizing care, since they described interest in the inclusion of this evaluation instrument.

It is necessary to implement strategies to translate the knowledge to improve the NB pain management.

The professionals that work with the NB should be continuously qualified and trained so that the theoretical knowledge reflects on the professional practice.

Before understanding the important meaning of the pain analysis, the professionals still do not use scales for this process, and there are no standardized non-pharmacological measures for the relief.

The use of protocols and scales for the evaluation of the neonatal pain indicators represents a practice to be reconsidered.

The influence of the organizational factor stands out in the engagement-disengagement of these professionals with appropriate practices of pain relief supporting interventions targeted at the humanized neonatal care.

There is a divergence between what is considered prescribed and the administered, indicating a gap between the practice and the existing knowledge. The attitudes must be changed and exploited for the best available evidence.

It was observed that the NB are frequently exposed to pain, and the low frequency of pharmacological or nonpharmacological interventions reinforces the sub treatment of this condition.

\section{PERCEPTION OF THE PAIN STIMULUS BY THE NU- RSING STAFF}

In all the articles, except number 8 that does not provide this information, the nursing professionals acknowledged that the NB feels pain ${ }^{10-16,18-29}$. In this sense, the knowledge went through modifications since before the 1970s it was believed that the NB did not have neuroanatomical and neuroendocrine elements vital to the perception of the pain stimulus ${ }^{15}$. The procedures considered the most disturbing were the venous punctures and excessive manipulation/ repositioning. Besides, routine activities such as change of diapers and weighing were also mentioned ${ }^{10}$. 
Regarding the signs of pain, the alterations of the face, crying, irritation, excessive limb movements, tachycardia, and hyposaturation ${ }^{16}$ were the ones that stood out the most.

\section{EVALUATION OF THE NEONATAL PAIN}

The objective evaluation of the pain in the NB should be carried out via scales that add physiological and behavioral parameters with the purpose of obtaining information regarding the individual responses to pain $^{26}$.

In respect to the use of scales, articles $3,7,11,13,14,15,16,18$, and 20 confirmed their application and awareness on the part of the professionals. The most used scales to evaluate the pain in the NB and mentioned in these studies were the Neonatal Facial Coding System (NFCS), which uses facial mimicry to analyze the pain, and the Neonatal Infant Pain Scale (NIPS), which adds behavioral indicators and a physiological predictor for this evaluation $^{12,16,20,22-25,27,29}$.

Articles 1, 2, 5, 6, and 12 revealed the lack of knowledge/use of the scales on the part of the professionals ${ }^{10,11,14,15,21}$. The absence of the verbalization from the child was pointed out as the main difficulty to perform this evaluation, followed by the unpreparedness of the professionals, who claimed to ignore this new instrument in the assistance of the pain management ${ }^{22}$. Despite this data, article 11 emphasized the importance of the pain evaluation considered by the nursing staff. "This evaluation would bring higher comfort and well-being to the patient since more effective analgesia could be performed ${ }^{20}$ ".

Articles 4, 8, 9, 10, 17, and 19 did not addressed this informa$\operatorname{tion}^{13,17-19,28}$.

\section{NON-PHARMACOLOGICAL ACTIONS USED FOR THE RELIEF OF PAIN}

When the care performed to prevent the pain were analyzed, it was highlighted, through the articles $1,5,6,7,8,10,12,16$, and 17 , the use of a sweetened solution (non-nutritive suction with gauze and breast milk, or glucose $25 \%$ ), the wrapping of the $\mathrm{NB}$, change of decubitus, breastfeeding associated to the skinto-skin contact, promotion of the humanized care, and sleeping periods, and precautions regarding the environment's light and acoustics ${ }^{10,14-17,19,21,25,26}$.

Exceptionally, article 9 presented the improvements in the pain management after using aquatic therapy. Through the study, an improvement of the heart rate, respiratory rate, and peripheral oxygen saturation of the newborn after this therapy ${ }^{18}$.

\section{REGISTRY OF THE NON-PHARMACOLOGICAL ANALGESIA MEASURES IN THE MEDICAL RECORDS}

The non-registration of the non-pharmacological measures or possible complications of these interventions in the medical records are one of the main challenges for the effective neonatal pain management $t^{28}$.

Only four articles out of the exposed disclosed this information in their studies. In the performed interviews, the professionals of the articles 15,19 , and 20 confirmed not performing this note ${ }^{24,28,29}$. By contrast, the nurses interviewed in article 14 acknowledged the importance of the registration of the pain evaluation and treatment in the NB medical record and confirmed such practice was often carried out ${ }^{23}$.

\section{CONSEQUENCES OF THE NEONATAL PAIN}

The acknowledgment on the part of the professionals about the harmful effects in the development of the NB submitted to painful procedures is little exploited in the studies in question, is described only in articles 1,12 , and $14^{10,21,23}$.

It is known that the exposure to pain stimulus as of 16 weeks generates consequences in the short and long-term ${ }^{23}$. These consequences include alteration of the sensitivity, behavioral and physiological alterations ${ }^{10}$. These consequences are also explained due to the immature plasticity of the brain, which leads to, for example, the decrease of the pain threshold during the development ${ }^{21}$.

\section{TRAINING INCLUDING THIS THEME}

The health professionals find it difficult to diagnose and deal with the NB pain due to a deficiency in the basic knowledge of the painful experience by the $\mathrm{NB}^{10}$.

When examining the articles regarding the source of knowledge acquired by the professionals, it is observed that this data is also little inspected. Articles 1, 2, 13, 15, and 19 revealed that most health professionals received information on neonatal pain throughout their education in a technical course, undergraduate, or graduate programs, and there is not a continuous practice training in the maternity ward ${ }^{10,11,22,24,28}$.

It is noticed that other themes are prioritized, such as breastfeeding, hospital infection, intravenous therapy, among others ${ }^{28}$. However, it is believed that the continuous education, promoted via training and qualifications, is the foundation for the quest and inclusion of new or not well-disclosed knowledge in the nursing care practice, as well as the evaluation of pain in the NB.

\section{RATIONALE}

Nowadays, due to the technological advances, the amount of painful and invasive procedures have increased, making the recognition, evaluation, and implementation of the pain management in the NB indispensable in the maternity wards. In this sense, the nurse has the duty of contributing to the improvement of the care to the NB submitted to pain.

It is observed that the knowledge of the nursing staff is being changed over the years. For example, the nearly-unanimous recognition of pain on the part of the professionals interviewed in the articles under study is highlighted, in opposition to prior information when the professionals stated that the NB did not have pain stimulus. Despite this advance, the fact that not all workers use the scales to evaluate the pain is disapproved since they were elaborated in the late 80 s and, therefore, should be mastered by those working in neonatology. Also, it is underlined that this procedure is not being performed systematically, probably tak- 
ing into consideration subjective criteria, without scientific basis. Furthermore, in respect to knowledge, the little exploitation and disclosure of this theme in the continuing education programs and investigations regarding the insight of the professionals on the consequences of the neonatal pain is criticized.

Regarding the attitudes and practices, it is worth mentioning that even without the proper evaluation, the professionals seek to relieve the NB pain. They try different approaches as the sweetened sucking also called a sugary pacifier in several articles, reducing the light and noise, and controlling the unit temperature, or even in the asking the physician to prescribe sedatives or analgesics. The few notes of the non-pharmacological measures used for the neonatal pain management and the low approach of this theme in the researches revealed the great problem and challenge for the improvement of these procedures, since it enables a major communication failure between the teams and shifts, and also impairs the veracity of auditing.

\section{CONCLUSION}

It is pointed out via this study the need to include this theme in the undergraduate, graduate courses, training, and qualifications in the maternity wards in a continuous way so that the professional manages to relate theory and practice and then offer the best therapy to the NB and guidance to the mothers.

\section{REFERENCES}

1. Merskey H, Albe-Fessard DG, Bonic JJ. Pain terms: a list with definitions and notes on usage. Recommended by the International Association for Study of Pain (IASP) Subcommittee on Taxonomy. Pain. 1979;6(3):249-52.

2. Blackburn S. Environmental impact of the NICU on developmental outcomes. J Pediatr Nurs. 1998;13(5):279-89.

3. Guinsburg R. [Assessing and treating pain in the newborn]. J Pediatr. 1999;75(3):14960. Portuguese.

4. Anand KJ, Craig KD. New perspectives on definition of pain. Pain. 1996;67(1):3-6; discussion 209-11.

5. Sousa BB, Santos MH, Sousa FG, Ferrario AP, Paiva SS. Avaliaçáo da dor como instrumento para o cuidar de recém-nascidos pré-termo. Texto Contexto Enferm. 2006;15 (Esp):88-96

6. Souto SP. A dor no recém-nascido: o desafio da avaliação. Nursing. 2008;233.

7. Parras C. Dor no recém-nascido. São Paulo: Hospital Israelita Albert Einstein; 2002. 4p.

8. Lockridge T. Following the learning curve: the evolution of kinder, gentler neonatal respiratory technology. J Obstet Gynecol Neonatal Nurs. 1999;28(4):443-55.

9. Kazanowski MK, Laccetti MS. Intervençôes para alívio da dor. Dor: Fundamentos, abordagem clínica e tratamento. Rio de Janeiro: Guanabara Koogan; 2005.
10. Mendes LC, Fontenele FC, Dodt RC, Almeida LS, Cardoso MV, Silva CB. A dor no recém-nascido na unidade de terapia intensiva neonatal. Rev Enferm UFPE online. Recife. 2013;7(11):6446-54.

11. Alves FB, Fialho FA, Dias IM, Amorim TM, Salvador M. Dor neonatal: a percepçáo da equipe de enfermagem na unidade de terapia intensiva neonatal. Revista Cuidarte. 2013;1(4):510-5.

12. Wieckzorkievicz AM, Maia ED, Lamin S, Alcantara SB. Percepção do enfermeiro em relação à utilização de escalas de avaliação de dor em recém-nascidos. Saúde Meio Ambient. 2013;2(2):20-31.

13. Caetano EA, Lemos NR, Cordeiro SM, Pereira FM, Moreira DS, Marques SM O recém-nascido com dor: atuaçáo da equipe de enfermagem. Esc Anna Nery. 2013;17(3):439-45.

14. Rosário SS, Fernandes AP, Araújo CS, Paiva WW, Batista FW, Monteiro AI, et al Assistência de enfermagem ao recém-nascido com dor em uma unidade de terapia intensiva neonatal. Rev Enferm UFPE. 2014;8(Suppl 1):2382-9.

15. Capellini VK, Daré MF, Castral TC, Christoffel MM, Leite AM, Scochi CG. Conhecimento e atitudes de profissionais de saúde sobre avaliação e manejo da dor neonatal. Rev Eletr Enf. 2014;16(2):361-9.

16. Amaral JB, Resende TA, Contim D, Barichello E. Equipe de enfermagem diante da dor do recém-nascido pré-termo. Esc Anna Nery. 2014;18(2):241-6.

17. Cordeiro RA, Costa R. Métodos não farmacológicos para alívio do desconforto e da dor no recém-nascido: uma construção coletiva da enfermagem. Texto Contexto Enferm. 2014;23(1):185-92.

18. Ribeiro LF, Xavier GN, Kairala AL, Oliveira MS. A utilização da terapia aquática como método de reduçáo da dor em UTI neonatal (relato de caso). 2015;19-22.

19. Leite AM, Silva AC, Castral TC, Nascimento LC, Sousa MI, Scochi CG. Amamentação e contato pele-a-pele no alívio da dor em recém-nascidos na vacina contra hepatite B. Rev Eletr Enf. 2015;17(3):1-8.

20. Blasi DG, Candido LK, Tacla MT, Ferrari RA. Avaliaçâo e manejo da dor na criança: percepção da equipe de enfermagem. Semina: Ciências Biológicas e da Saúde, Londrina. 2015;36(1 Suppl):301-10

21. Araujo GC, Miranda JO, Santos DV, Camargo CL, Nascimento Sobrinho CL, et al Dor em recém-nascidos: identificação, avaliaçấo e intervençôes. Rev Baiana Enfermagem. 2015;29(3): 261-70.

22. Monfrim XM, Saraiva LA, Moraes CL, Viegas AC. Escala de avaliaçáo da dor: percepção dos enfermeiros em uma unidade de terapia intensiva neonatal. Rev Enferm UFSM. 2015;5(1):12-22

23. Costa T, Rossato LM, Bueno M, Secco IL, Sposito NP, Harisson D, et al. Conhecimento e práticas de enfermeiros acerca do manejo da dor em recém-nascidos. Rev Esc Enferm USP. 2017;51:e03210.

24. Soares AC, Caminha MF, Coutinho AC, Ventura CM. Dor em unidade neonatal: conhecimento, atitude e prática da equipe de enfermagem. Cogitare Enferm. 2016;21(2):1-10

25. Rodrigues JB, Souza DS, Werneck AL. Identificaçăo e avaliaçấo da percepçáo dos profissionais de enfermagem em relaçáo a dor/desconforto do recém-nascido. Arq Ciênc Saúde. 2016;23(1) 27-31.

26. da Costa KF, Alves VH, Dames LJ, Rodrigues DP, Barbosa MT, Rosa MT. Manejo clínico da dor no recém-nascido: percepção de enfermeiros da unidade de terapia intensiva neonatal. Rev Pesq Cuid Fundamental. 2016;8(1):3758-69.

27. Martins SW, Enumo SR, Paula KM. Manejo da dor neonatal: influência de fatores psicológicos e organizacionais. Estud Psicol. 2016;33(4):633-44.

28. Christoffel MM, Castra TC, Daré MF, Montanholi LL, Gomes AL, Scochi CG. Atitudes dos profissionais de saúde na avaliaçấo e tratamento da dor neonatal. Esc Anna Nery. 2017;21(1): e20170018.

29. Sposito NP, Rossato LM, Bueno M, Kimura AF, Costa T, Guedes DM. Assessment and management of pain in newborns hospitalized in a Neonatal Intensive Care Unit: a cross-sectional study. Rev Lat Am Enfermagem. 2017;25:e2931. English, Portuguese, Spanish. 